\title{
EDUKASI PASAR MODAL DI MADRASAH ALIYAH MUHAMMADIYAH PEKANBARU
}

\author{
Siti Samsiah*, Siti Hanifa Sandri, Bakaruddin \\ Prodi Keuangan \& Perbankan, Fakultas Ekonomi dan Bisnis \\ Universitas Muhammadiyah Riau \\ email: siti.samsiah@umri.ac.id
}

\begin{abstract}
The capital market is a market (place, in the form of a building) prepared to trade stocks, bonds, and other types of securities using the services of stockbrokers. To add to the opening insights on the introduction of capital markets in Indonesia, the introduction of trading mechanisms on stocks and the steps to become investors in the capital market addressed to school teachers and students by practitioners who have been directly involved in the capital market in order to support the interests, knowledge and improving soft skill of teachers and students especially related to how to invest in capital market.

This method of community service activities using lecture methods, direct demonstrations practiced by participants, and question and answer.

Evaluation of activities generally works well and satisfies participants and training instructors. Participants hope that in the following years can be given the opportunity to get similar training. Overall activities of community empowerment through education of capital market run well and smoothly. This training provides skills and knowledge about capital market activities to teachers and learners as a provision to start a flexible and controllable side business.
\end{abstract}

Keywords: Capital market, Investation, Stock

\section{PENDAHULUAN}

Pasar modal (capital modal) memiliki posisi yang strategis dalam pembangunan ekonomi nasional. Pertumbuhan suatu pasar modal sangat tergantung dari kinerja perusahaan efek. Pasar modal melakukan kegiatan yang berhubungan dengan penawaran umum dan perdagangan efek, di mana perusahaan publik yang berhubungan dengan efek akan dapat menerbitkan perdagangan, serta lembaga, dan profesi yang berkaitan dengan efek.

Pasar modal bertindak sebagai perantara para investor dengan perusahaan ataupun institusi pemerintah melalui perdagangan instrumen dengan jangka panjang seperti obligasi, saham, dan lainnya.

Sedangkan menurut Undang-undang Pasar Modal No. 8 tahun 1995 berisi: "Pasar Modal yaitu sebagai suatu kegiatan yang bersangkutan dengan penawaran umum dan perdagangan efek, perusahaan publik yang berkaitan dengan efek yang diterbitkannya, serta lembaga dan profesi yang berkaitan dengan efek."

Untuk memperluas wawasan pembuka tentang pasar modal di Indonesia, dapat dimulai melalui pengenalan mekanisme perdagangan pada saham serta langkah-langkah untuk menjadi investor di pasar modal yang ditujukan kepada guru-guru sekolah dan siswa oleh praktisi yang sudah terjun langsung di pasar modal yang bertujuan untuk menunjang minat, pengetahuan serta meningkatkan 
soft skill guru dan siswa khususnya berhubungan dengan bagaimana berinvestasi di pasar modal.

Berdasarkan penjelasan yang terdapat pada latar belakang dapat diketahui permasalahan yaitu bagaimana cara berinvestasi di pasar modal bagi guru - guru maupun peserta didik.

\section{METODE PENGABDIAN}

$\begin{array}{llr}\text { Metode } & \text { dalam } & \text { kegiatan } \\ \text { pengabdian } & \text { masyarakat } & \text { ini } \\ \text { menggunakan } & \text { metode } & \text { ceramah }\end{array}$
menggunakan metode ceramah, demonstrasi langsung dipraktekkan oleh peserta, serta tanya jawab. Metode ceramah digunakan untuk menyampaikan pengetahuan tentang teori investasi pasar modal. Demontrasi digunakan untuk memberikan pengetahuan peserta bagaimana cara membeli saham di bursa efek Islamic Indonesia. Tanya jawab digunakan untuk melengkapi hal - hal yang belum terakomodasi oleh kedua metode di atas.

\section{Kegiatan Pelatihan}

a. Tahap Persiapan

Sebelum melakukan kegiatan pelatihan, pelaksana kegiatan melakukan konsultasi dengan anggota yang lain. Kemudian melakukan observasi terhadap sasaran dan melakukan koordinasi kepada pihak yang bersangkutan.

b. Tahap Pelaksanaan Kegiatan Pelatihan Edukasi Pasar Modal ini akan dilaksanakan sebanyak dua sesi.

1) Pada sesi pertama

Peserta akan diberikan materi seputar berinvestasi dan cara membeli saham di pasar modal. Penyampaian materi menggunakan media power point. Materi diberikan oleh ketua dan anggota pelaksana.
2) Pada sesi kedua, peserta akan diberikan praktek langsung yakni mempraktekkannya pada aplikasi transaksi di pasar modal.

\section{Materi dan Metode}

Pasar Modal merupakan kegiatan yang berkaitan dengan penawaran umum dan perdagangan efek, perusahaan publik yang berkaitan dengan efek yang diterbitkannya, serta lembaga dan profesi yang berkaitan dengan efek. (Darmaji, 2006:1)

Pasar Modal bertindak sebagai penghubung antara para investor dengan perusahaan ataupun institusi pemerintah melalui perdagangan instrumen keuangan jangka panjang seperti Obligasi, Saham dan lainnya. Hingga saat ini, instrumen yang diterbitkan dan diperdagangkan di pasar modal indonesia antara lain: Saham, Obligasi, Rights, Waran dan Kontrak Berjangka (Future)

Kegiatan pengabdian ini diawali dengan survey Tim ke lokasi pengabdian masyarakat dan berkoordinasi dengan pihak setempat.

Kegiatan pengabdian pada masyarakat dilaksanakan dengan metode ceramah, demonstrasi/ pelatihan dan tanya jawab yang dilaksanakan selama 1 hari. Adapun tahapan - tahapan dalam pelaksanaan kegiatannya adalah sebagai berikut :

1. Metode presentasi

Metode ini digunakan untuk menyampaikan materi pasar modal

2. Metode Prektek Langsung

Metode ini digunakan untuk mempraktekkan langsung bagaimana membeli saham di pasar modal

Table 3.1 Jadwal dan Materi Kegiatan

\begin{tabular}{|l|l|l|l|l|l|l|}
\hline \multirow{2}{*}{ No } & \multirow{2}{*}{ Materi kegiatan } & \multicolumn{5}{|c|}{ Pertemuan } \\
\cline { 3 - 6 } & & 1 & 2 & 3 & 4 & 5 \\
\hline 1. & $\begin{array}{l}\text { Konsep Pasar } \\
\text { Modal }\end{array}$ & & & & & \\
\hline
\end{tabular}




\begin{tabular}{|l|l|l|l|l|l|l|}
\hline 2. & $\begin{array}{l}\text { Jenis-jenis Produk } \\
\text { Pasar Modal }\end{array}$ & & & & & \\
\hline 3. & $\begin{array}{l}\text { Kelembagaan dan } \\
\text { Pelaku }\end{array}$ & & & & & \\
\hline 4. & $\begin{array}{l}\text { Strategi investasi } \\
\text { di Pasar Modal }\end{array}$ & & & & & \\
\hline 5. & $\begin{array}{l}\text { Resiko Investasi } \\
\text { di Pasar Modal }\end{array}$ & & & & & \\
\hline
\end{tabular}

\section{HASIL DAN PEMBAHASAN}

Pengabdian kepada masyarakat ini dimulai dengan melakukan tahap persiapan, tahap ini dilakukan survey dan observasi dan permohonan izin kepada Kepala Sekolah Madrasah Aliyah Muhammadiyah Pekanbaru sebagai tempat pelaksanaan pengabdian ini. Selain itu pada tahap persiapan juga mencari informasi jumlah peserta dan kegiatan peserta sebelum diadakan pelatihan kepada guru-guru maupun pederta didik Madrasah Aliyah Muhammadiyah Pekanbaru. Setelah waktu pelaksanaan disepakati, tim dari Dosen Keuangan dan Perbankan Fakultas Ekonomi dan Bisnis menyusun jadwal pelaksanaan dan membuat kesepakan dengan pihak sekolah Madrasah Aliyah Muhammadiyah Pekanbaru.

Pada tahap pelaksanaan kegiatan ini dimulai dengan tahapan persiapan. Dilanjutkan dengan tahapan pelaksanaan kegiatan dilaksanakan sesuai dengan waktu yang telah di sepakati pada tanggal 24 Maret 2018 bertempat di aula Madrasah Aliyah Muhammadiyah Pekanbaru. Tahapan pelaksanaan kegiatan dimulai dengan menjelaskan materi tentang pengetahuan berinvestasi di pasar modal, membaca peluang-peluang keuntungan berinvestasi di saham dan cara membeli saham. Tahapan pelaksanan selanjutnya yaitu demonstrasi secara langsung transaksi pembelian saham pasar modal.

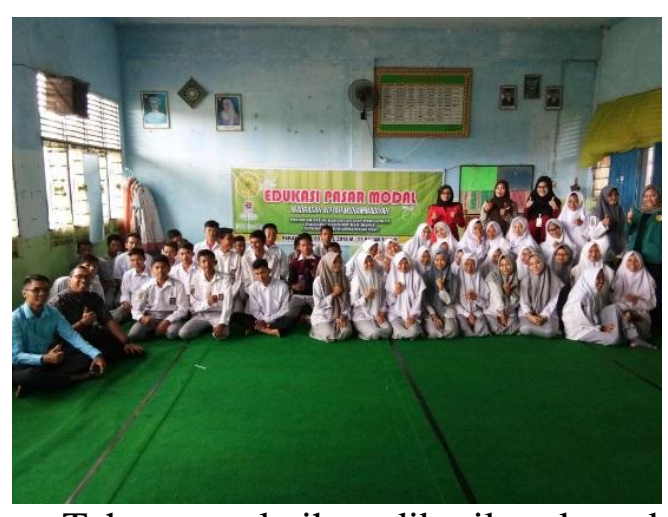

Tahapan pelatihan diberikan kepada setiap peserta berupa uraian atau langkah-langkah pembelian saham. Arahan dan tanya jawab berlangsung pada saat kegiatan berlangsung, instruktur menjelaskan langkahlangkah pembelian saham. Pelatihan berlangsung mulai pukul $08.00-12.00$ WIB.

Evaluasi pada tahap pertama telah sesuai dengan indikator dan rancangan evaluasi diperoleh data sebgai berikut:

1. Jumlah peserta yang hadir sebanyak 51 orang dari 75 peserta sehingga tingkat kehadiran mencapai $75 \%$.

2. Peserta sangat terlihat antusias selama mengikuti kegiatan hingga pelatihan selesai Seluruh peserta mengikuti pelatihan edukasi pasar modal dan praktek langsung cara pembelian saham di pasar modal.

3. Setelah dilakukan pelatihan diharapkan guru-guru maupun peserta didik Madrasah Aliyah Muhammadiyah Pekanbaru dapat membuat kegiatan yang menambah penghasilan keluarga. Selain itu, diharapkan para peserta pelatihan dapat mengembangkan ilmu yang telah didapat ke anak didiknya sehingga mereka memiliki keahlian dan pendapatan.

\section{KESIMPULAN}

Evaluasi kegiatan secara umum berhasil dengan baik dan memuaskan peserta maupun instruktur pelatihan. Peserta berharap 


\begin{abstract}
ditahun-tahun berikutnya dapat diberikan kesempatan untuk mendapatkan pelatihan sejenis.

Secara keseluruhan kegiatan pemberdayaan usaha masyarakat melalui edukasi pasar modal berjalan baik dan lancar. Pelatihan ini memberikan keterampilan dan pengetahuan tentang kegiatan pasar modal kepada guru-guru maupun peserta didik sebagai sebagai bekal untuk memulai usaha sampingan yang fleksibel dan dapat dikontrol.

Peserta pelatihan disarankan untuk terus dapat mengembangkan ilmu yang telah diterima, karena semakin banyak ilmu yang didapat akan menambah pendapatan tanpa harus mengeluarkan modal yang besar. Selain itu seringnya mengikuti dan menekuni kegiatan tentang pasar modal dapat mengembangkan nilai positif dan menjadikan individu yang berkualitas.
\end{abstract}

\title{
DAFTAR PUSTAKA
}

1. Bursa Efek Indonesia., 2010, Buku Panduan Indeks Harga Saham Bursa Efek Indonesia. Bursa Efek Indonesia.

2. Darmadji, Tjiptono dan Hendy M. Fakhruddin. 2001. Pasar Modal di Indonesia. Jakarta: Salemba Empat

3. IDX Indonesia, http://www.idx.co.id diakses pada tanggal 23 Maret 2018

4. Rusdin. 2008. "Pasar Modal". Cetakan kedua. Bandung:Alfabeta.

5. Samsul, mohamad (2006). Pasar modal \& Manajemen Portofolio, edisi Pertama. Jakarta: Erlangga. 